\title{
Program Intensive Course di Pondok Pesantren Pada Masa Pandemi
}

\author{
Laudria Nanda Prameswati, ${ }^{1}$ Aliza Salsabilla, ${ }^{2}$ Frida Akmalia ${ }^{3}$ \\ ${ }^{1,2}$ Institut Agama Islam Negeri Kediri, Indonesia \\ ${ }^{3}$ Universitas Pendidikan Indonesia, Indonesia \\ 1laudria.nanda@gmail.com, 2aliza.salsabilla82@gmail.com,3fridaakmalia26@upi.edu
}

\begin{abstract}
This study aims to determine the implementation of the Intensive Course (IC) program in Islamic boarding schools to identify the challenges, strengths, and weaknesses faced in its implementation. The method in this research uses qualitative research exploration. Three data collection techniques were used: in-depth interviews, observation, and documentation. The results of this study describe the implementation of the IC program during the pandemic, the challenges in its implementation consist of the presence of students, teaching materials, and a relatively short time, as well as the advantages and disadvantages of the learning program. This study only describes one Islamic boarding school in Kediri, namely Syarif Hidayatullah Islamic Boarding School. These results are helpful as an overview of IC during a pandemic and a reference for fut ure research. This study provides evidence-based research information, especially on its implementation at the Syarif Hidayatullah Islamic boarding school.
\end{abstract}

Keywords: Intensive Course Program, Islamic Boarding School, Learning

\begin{abstract}
Abstrak
Tujuan dari penelitian ini adalah untuk mengetahui implementasi program Intensive Course (IC) di pondok pesantren, mengidentifikasikan tantangan, kelebihan, dan kekurangan yang dihadapi dalam implementasinya. Metode dalam penelitian ini menggunakan kualitatif dengan eksplorasi studi. Tiga teknik pengumpulan data yang digunakan, yaitu: wawancara, observasi, dan dokumentasi. Hasil dari penelitian ini menggambarkan implementasi program IC selama pandemi, tantangan dalam pelaksanannya terdiri dari kehadiran santri, bahan ajar, dan waktu yang relatif singkat, serta kelebihan dan kekurangan program pembelajaran. Penelitian ini hanya menggambarkan satu pondok pesantren yang ada di Kota Kediri, yaitu Pondok Pesantren Syarif Hidayatullah. Hasil ini berguna sebagai gambaran tentang IC pada masa pandemi dan rujukan untuk penelitian di masa mendatang. Studi ini memberikan informasi penelitian berbasis bukti terutama pada pelaksanaannya di Pondok Pesantren Syarif Hidayatullah.
\end{abstract}

Kata Kunci: Program Intensive Course, Pondok Pesantren, Pembelajaran 


\section{Pendahuluan}

Dalam kurun waktu lima tahun terakhir, program intensif menjadi kajian penting diberbagai negara seperti: Filipina, ${ }^{1}$ India, ${ }^{2}$ dan Indonesia, ${ }^{3}$ Pasalnya program ini diketahui memiliki manfaat yang dapat mengasah kemampuan peserta didik.Program intensif merupakan salah satu program unggulan yang diberikan oleh sebuah lembaga pendidikan formal seperti kampus dan sekolah atau lembaga kursus yang menyediakan layanan kebahasaan. ${ }^{4}$ Menurut Booti yang dikutip oleh Faren Rosalina dan Loli Safitri, IC adalah mata kuliah yang mencakup beberapa ketrampilan seperti: membaca, menulis, mendengarkan, dan berbicara. ${ }^{5}$

Beberapa penelitian terdahulu mengemukakan bahwa program IC telah diterapkan di beberapa lembaga pendidikan atau kursus. Penelitian yang dilakukan oleh Faren Rosalia dan Loli Safitri yang menyatakan bahwa IC termasuk mata kuliah yang dikhususkan untuk mahasiswa program studi bahasa Inggris di kampus untuk mahasiswa baru. Setelah dianalisis, mata kuliah IC termasuk mata kuliah yang sulit. Kesulitan terbanyak dialami mahasiswa baru pada saat ketrampilan membaca. Namun, mata kuliah IC tetap diberikan untuk mahasiswa baru agar mereka tidak kesulitan menghadapi materi-materi bahasa Inggris di semester yang akan datang. Hal ini menjadi salah satu bahan evaluasi dosen agar permasalahan tersebut teratasi dengan menerapkan program IC lebih kreatif dan inovatif. ${ }^{6}$

Menurut Ratna yang ditulis di dalam skripsinya, menyatakan bahwa salah satu program yang diyakini dapat meningkatkan kemampuan berbahasa seseorang adalah dengan diberikan strategi yang menyenangkan, salah satunya yaitu program IC di

1 Abdul Haiy Abdul Sali dan Arlyne Canales Marasigan, "Madrasah Education Program Implementation in the Philippines: an Exploratory Case Study," International Journal of Comparative Education and Development 22, no. 3 (2020): 203, https://doi.org/10.1108/IJCED-06-2019-0034.

${ }^{2}$ Sita Mishra dan Rajendra Nargundkar, "An Analysis of Intensive Mode Pedagogy in Management Education in India," International Journal of Educational Management 29, no. 4 (1 Januari 2015): 406, https://doi.org/10.1108/IJEM-04-2014-0050.

${ }^{3}$ Frida Akmalia dan Syihabuddin, "Taqwîm Al Barnāmij Al Mukatstsaf Lita'lîm Al Lughah Al'arabiyyah Fî Al Madrasah Al Mutawassitah Al Islāmiyyah Al Hukūmiyyah Al Tsāniyah Kediri," AlMi'yar 3, no. 1 (2020).

${ }^{4}$ Sofi Yunianti, Teguh Adimarta, dan Vega Hesmatantya, "Peningkatan Kualitas Pembelajaran Berkarakter pada Perkuliahan Intensive Course," Didaktis 15, no. 2 (2015): 56, http://dx.doi.org/10.30651/didaktis.v15i2.81.

5 Faren Rosalina dan Loli Safitri, "An Analysis of Students' Difficulties In Learning Intensive Course at The First Semester Students of State Islamic Institute of Bukittinggi Academic Years 2019/2020," Indonesian Journal of Learning Studies 1, no. 11 (2021): 73.

${ }^{6}$ Rosalina dan Safitri, 34. 
kampus. ${ }^{7}$ Maka dari itu, beberapa kampus yang menyediakan program studi bahasa Inggris menyediakan program mata kuliah keterampilan bahasa Inggris 28 jam perminggu yang disebut IC. Program IC diberikan untuk mahasiswa awal dan akhir dengan tujuan yang berbeda. Untuk mahasiswa awal diberikan program IC agar mereka siap dalam mengikuti pembelajaran-pembelajaran yang selanjutnya pada semester pertama. Sedangkan tujuan dari program IC bagi mahasiswa akhir di kampus yaitu mempersiapkan lulusan program studi bahasa Inggris memiliki kemampuan yang layak dalam mengajar bahasa Inggris di berbagai jenjang pendidikan. ${ }^{8}$

Sebenarnya, program IC telah dilakukan di beberapa pondok pesantren, salah satunya yaitu Pondok Pesantren Mamba'us Sholihin Suci Manyar Gresik. Penelitian yang dilakukan oleh Fitri Hidayati, dkk menyatakan bahwa pondok tersebut menerapkan program IC yang berbasis kebahasaan seperti bahasa Arab dan bahasa Inggris. Namun, dalam penelitian Fitri berfokus pada manajemen pengorganisasian program bahasa Arab. Hasil dari penelitian tersebut menyatakan bahwa pondok pesantren tersebut menggunakan sistem koordinasi dan terstruktur untuk memanajemen program intensif bahasa Arab. ${ }^{9}$

Penelitian lain juga dilakukan oleh Nurul Hidayatul Amalina dan Muh Nashirudin melaporkan bahwa Pondok Pesantren Ta'mirul Islam menerapkan program wajib berbahasa Arab untuk santri tingkat tsanawiyah. Setiap guru memberikan penjelasan kepada peserta didik dengan tujuan agar mereka dapat menguasai dan memahami bahasa Arab dengan tujuan melatih kemampuan berbahasa santri. Meski di awal penerapannya mereka merasa keberatan terutama untuk yang tidak terlalu suka dengan mata pelajaran bahasa Arab dan untuk yang belum pernah mempelajari bahasa Arab sama sekali. Namun, guru tetap memberikan semangat dan reward setiap akhir pekan kepada mereka yang telah berusaha berbicara menggunakan bahasa Arab meski masih terdapat kalimat yang kurang tepat. ${ }^{10}$

\footnotetext{
${ }^{7}$ Ratna, "English Learning Strategies Used by Students At English 'Intensive Course' in Jombang” (Malang, Universitas Brawijaya, 2017), 16.

${ }^{8}$ Dinar Dipta dan Lies Amin Lestari, "Tenses Usage in Pre and Post Test Compositions of Intensive Course Program," Jurnal Mahasiswa Unesa 4, no. 2 (2015): 14.

${ }^{9}$ Fitri Hidayati dkk., "Manajemen PengorganisasianProgram Bahasa Arab di Pondok Pesantren Salaf," Tarling: Journal of Language Education 3, no. 1 (2019): 118, https://doi.org/tarling.v3i1.2031.

${ }^{10}$ Nurul Hidayatul Amalina dan Muh. Nashirudin, "Analisis Proses Pembelajaran Bahasa Arab Pada Tingkat Tsanawiyah di Pondok Pesantren Ta'mirul Islam," Jurnal Tatsqif: Jurnal Pemikiran dan Penelitian Pendidika 15, no. 2 (2017): 18, https://doi.org/10.20414/jtq.v15i2.7.
}

Tribakti: Jurnal Pemikiran Keislaman

Volume 32, Nomor 1, Juli 2021 
Untuk menghadapi modernisasi yang terjadi di dalam sistem pendidikan, Pondok Pesantren Puncak Darus Salam ingin membentuk generasi masa depan yang mampu bersaing tidak hanya di bidang ilmu agama tetapi juga mumpuni di bidang ilmu teknologi, sains dan bahasa. Bahasa Inggris diyakini sebagai bahasa Internasional dan digunakan oleh sebagian besar negara. Maka dari itu, pondok pesantren pada tahun 2009 mulai menerapkan bahasa Inggris sebagai bahasa asing yang wajib dipelajari oleh santri. Diharapkan dengan adanya program intensif bahasa Inggris dapat digunakan sebagai alat berbagi informasi mengenalkan Islam di belahan dunia. ${ }^{11}$

Meski telah banyak penelitian yang dilakukan tentang program intensif di Indonesia, tetapi masih sedikit penelitian-penelitian tentang pelaksanaan program intensif di pondok pesantren terutama saat pandemi. Oleh karena itu, dengan adanya penelitian ini diharapkan dapat dijadikan sebagai salah satu sumber referensi untuk penelitian di masa mendatang. Selain itu, dengan adanya penelitian ini dapat dijadikan sebagai bahan evaluasi untuk program intensif selanjutnya.

Seperti yang diketahui bahwa pendidikan di Indonesia tidak lepas dari pondok pesantren. Meski di zaman modern seperti sekarang ini, pondok pesantren tetap mempertahankan eksistensinya dan fungsinya sebagai lembaga pendidikan ilmu-ilmu agama dan nilai norma keagamaan masyarakat. ${ }^{12}$ Menurut Mudjia Rahardjo yang dikutip oleh Zaenal Arifin dan Moh. Turmudi, sejarah pertumbuhan dan perkembangan pendidikan di Indonesia, pesantren telah menjadi local genius. Pesantren dianggap sebagai model pendidikan Islam yang memiliki keunggulan pada hal keilmuan maupun internalisasi nilai-nilai Islam. ${ }^{13}$ Bahkan di era modern ini, banyak orang tua yang cenderung memilih untuk memberikan pendidikan terbaik untuk anak dengan memberikan tanggungjawab sepenuhnya kepada pondok pesantren. ${ }^{14}$ Mengingat bahwa di era modern ini orang tua tidak hanya mengharapkan anak memiliki prestasi tinggi

${ }^{11}$ Mohammad Muchlis Solichin, "Intensive English Instructionin Pesantren (Study on Pondok Pesantren Puncak Darus Salam, Potoan Daja Palengaan Pamekasan)," OKARA: Jurnal Bahasa dan Sastra 12, no. 2 (2018): 260, https://doi.org/10.19105/ojbs.v12i12.1991.

12 Hendi Kariyanto, "Peran Pondok Pesantren dalam Masyarakat Modern," Edukasia Multikultura| 1, no. 1 (2019): 15.

${ }^{13}$ Zaenal Arifin dan Moh. Turmudi, "Character of Education in Pesantren Perspective: Study of Various Methods of Educational Character at Pesantren in Indonesia," Tribakti: Jurnal Pemikiran Keislaman 30, no. 2 (Juli 2019): 337, https://doi.org/10.33367/tribakti.v30i2.823.

${ }^{14}$ Marzuki dan Ahmad Masrukin, "Motif Orang Tua Santri di Pondok Pesantren HM Lirboyo," Tribakti: Jurnal Pemikiran Keislaman 30, no. 1 (2019): 168, https://doi.org/10.33367/tribakti.v30i1.667.

Tribakti: Jurnal Pemikiran Keislaman Volume 32, Nomor 2, Juli 2021 
tetapi juga bimbingan nilai moral, ilmu-ilmu agama sehingga kelak menjadi individu yang bermanfaat untuk negara, bangsa dan agama.

Kamus Besar Bahasa Indonesia (KBBI) menjelaskan bahwa pondok merupakan madrasah atau tempat tinggal yang digunakan untuk mengaji dan belajar agama. Kata pondok berasal dari bahasa Arab قَدُْنْ yang berarti hotel atau penginapan. ${ }^{15}$ Pesantren berasal dari kata santri dengan awalan "pe" dan akhiran "an" yang berarti tempat tinggal. ${ }^{16}$ Pesantren merupakan lembaga pendidikan yang dirintis, dikelola, dikembangkan oleh kiai. Pada dasarnya, pesantren adalah sebuah asrama pendidikan Islam tradisional tempat para santri tinggal bersama dan belajar ilmu-ilmu agama di bawah bimbingan kiai. ${ }^{17}$ Pondok pesantren merupakan lembaga pendidikan dan pengajaran agama yang diberikan kepada santri yang tinggal dalam pondok atau asrama dalam pesantren tersebut. ${ }^{18}$ Dewasa ini, terdapat jenis pondok pesantren modern yang mana pondok pesantren tetap memakai sistem tradisional (sorogan, wetonan, ataupun bandungan) dengan memberikan pendidikan nonformal serta penyelenggaraan pendidikan formal baik madrasah maupun sekolah umum dalam berbagai tingkatan. ${ }^{19}$

Pondok Pesantren Syarif Hidayatullah merupakan salah satu pondok yang ada di sekitar kampus IAIN Kediri. Pondok pesantren yang dikenal sebagai pondok modern ini berdiri pada tahun 2018 didirikan oleh Dr. KH. Ali Anwar, M. Ag., sebagai pendiri sekaligus pengasuh Pondok Pesantren Syarif Hidayatullah dengan visi "Menjadi pesantren yang luas pemahaman keislamannya, islami karakternya, dan canggih teknik pembelajarannya". Selain visi yang telah ditetapkan, pondok pesantren ini juga memiliki misi antara lain: mendalami ilmu-ilmu keislaman dengan berbagai mazhab dan firqohnya, mengamalkan ajaran Islam sesuai yang dianut masyarakat pendukungnya, menggunakan teknologi terkini dalam proses pembelajarannya. ${ }^{20}$

Pondok Syarif Hidayatullah memberikan dua program unggulan yang didapatkan oleh santri. Program tersebut adalah program reguler dan IC. Program reguler merupakan

15 Ahmad Darmadji, "Pondok Pesantren dan Deradikalisasi Islam di Indonesia," Millah XI, no. 1 (2011): 268, https://doi.org/10.20885/millah.vol11.iss1.art12.

${ }^{16}$ Khairurrijal, "Eksistensi Pondok Pesantren di Tengah Kemodernan Pesantren," Jurnal el-Hekam IV, no. 2 (2019): 34, http://dx.doi.org/10.31958/jeh.v4i2.2013.

${ }^{17}$ M Ferdinan, "Pondok Pesantren, Ciri Khas Perkembangannya," Jurnal Tarbawi 1, no. 1 (2019): 13, https://doi.org/10.26618/jtw.v1i1.348.

${ }_{18}$ Abdul Tolib, "Pendidikan di Pondok Pesantren Modern," Jurnal Risaalah 1, no. 1 (2015): 59.

19 Tolib, 61.

${ }^{20}$ Ali Anwar, "Syarif Hidayatullah Cyber Pesantren," Syarif Hidayatullah Cyber Pesantren (blog), 2018, https://syahidacyberpesantren.wordpress.com/.

Tribakti: Jurnal Pemikiran Keislaman

Volume 32, Nomor 1, Juli 2021 
kegiatan pembelajaran di pondok saat perkuliahan sedang berlangsung. Sedangkan program IC dilakukan saat perkuliahan sedang libur kenaikan semester. Dapat dikatakan bahwa di antara pondok pesantren di sekitar wilayah IAIN Kediri, hanya pondok Syarif Hidayatullah yang memberikan pembelajaran ketika libur semester. Tujuan dari program IC adalah untuk mengisi waktu liburan sehingga tidak sia-sia dengan waktu libur yang panjang digunakan untuk hal-hal yang bermanfaat seperti menambah dan meningkatkan keilmuan santri yang seluruhnya adalah mahasiswa dari IAIN Kediri meski di tengah pandemi.

Pemilihan pondok Syarif Hidayatullah karena satu-satunya pondok modern di sekitar kampus IAIN Kediri yang memanfaatkan masa liburan semester mahasiswa untuk menambah keilmuan dengan program IC. Meski di tengah pandemi yang tentu saja dalam penerapannya cukup berbeda daripada tahun-tahun sebelumnya, namun pengasuh dan pengurus pondok sepakat untuk melaksanakan pembelajaran IC dengan ketentuan tidak wajib diikuti oleh santri yang berada di luar Kediri.

\section{Metode}

Penelitian ini menggunakan metode studi kasus eksplorasi dan pendekatan penelitian menggunakan studi kasus kualitatif yang digunakan untuk mendapatkan informasi, mengemukakan sebuah ide-ide atau ketentuan mengenai implementasi program IC di pondok pesantren Syarif Hidayatullah kota Kediri di masa pandemi dan tantangan-tantangan yang dihadapi saat implementasinya. Responden dalam penelitian ini sebanyak delapan belas orang yang terdiri dari tiga pengurus pondok dan lima belas santri. Menurut Sugiyono yang dikutip oleh Ketut dan Jero, teknik pengumpulan data adalah cara yang digunakan untuk menghimpun serangkaian data dengan prinsip dan alat tertentu. $^{21}$ Pemerolehan data dilakukan dengan cara wawancara, observasi, dan dokumentasi.

Pertama, wawancara pada penelitian kualitatif merupakan pembicaraan terstuktur yang mempunyai tujuan untuk menggali informasi dengan mengajukan beberapa pertanyaan kepada narasumber. ${ }^{22}$ Dalam tahap wawancara ini dilakukan

${ }^{21}$ Ketut Agustini dan Jero Gede Ngarti, "Pengembangan Video Pembelajaran untuk Meningkatkan Motivasi Belajar Siswa Menggunakan Model R\&D,” Jurnal Ilmiah Pendidikan dan Pembelajaran 4, no. 1 (2020): 65 .

${ }^{22}$ Imami Nur Rachmawati, "Pengumpulan Data Dalam Penelitian Kualitatif: Wawancara," Jurnal Keperawatan Indonesia 11, no. 1 (2007): 35-40, https://doi.org/10.7454/jki.v11i1.184. 
wawancara dengan tiga pengurus Pondok Pesantren Syarif Hidayatullah yang terdiri dari Aulia selaku ketua umum, Khuma selaku sie keagamaan, dan Sinta sebagai sie pendidikan. Wawancara ini dilakukan secara langsung dengan memberikan daftar pertanyaan yang hendak diajukan namun pertanyaan dapat berkembang sesuai dengan jawaban dari responden. Selain pengurus, peneliti juga melakukan wawancara kepada lima belas santri yang dipilih secara purposive sampling. Menurut Bernard yang dikutip oleh Agus Purwanto, purposive sampling adalah metode yang digunakan untuk mencapai tujuan penelitian tertentu. Tidak ada batasan jumlah sampel yang dijadikan sebagai reponden, asalkan informasi yang ingin diperoleh dan dihasilkan. ${ }^{23}$

Kedua, observasi. Menurut Arikunto yang dikutip oleh Kiki Joesyiana observasi adalah salah satu teknik pengumpulan data dengan cara melakukan pengamatan secara langsung ke tempat yang akan diteliti. ${ }^{24}$ Observasi dilakukan ketika peneliti mengikuti kegiatan IC berlangsung kurang lebih selama 21 hari terhitung sejak tanggal 1 Februari 2021 sampai tanggal 20 Februari 2021. Kegiatan IC dilakukan pada hari Senin sampai dengan hari Sabtu mulai pukul 04.30 WIB sampai dengan 21.00 WIB sedangkan hari Ahad pembelajaran IC diliburkan.

Ketiga, dokumentasi yang merupakan bukti fisik (tulisan, foto, video, dan lainlain) yang telah dikumpulkan dan dapat dipakai kembali. ${ }^{25}$ Peneliti mengumpulkan dokumentasi berupa foto-foto dan video yang relevan dengan kegiatan IC.

Untuk memperluas penjelasan, peneliti juga menggunakan metode studi kepustakaan. Telaah literatur yang ada pada kepustakaan baik online (jurnal dan e-book) maupun offline, sehingga mendukung penjelasan dalam penelitian ini. Telaah pustaka dimaksudkan untuk mengetahui penelitian-penelitian terdahulu dan memberikan kajian tentang konsep kata kunci yang terdapat dalam judul penelitian. ${ }^{26}$

\footnotetext{
${ }^{23}$ Agus Purwanto, "Studi Eksplorasi Dampak Work From Home (WFH) Terhadap Kinerja Guru Selama Pandemi Covid-19," Journal of Education, Psycology, and Counselling 2, no. 1 (2020): 94.

${ }^{24}$ Kiki Joesyiana, "Penerapan Metode Pembelajaran Observasi Lapangan Pada Mata Kuliah Manajemen Operasional," Journal of Chemical Information and Modeling 53, no. 9 (2019): 1689-99.

${ }^{25}$ Queen Agave, "Teknik dokumentasi dan pelaporan dalam tataran klinik," Jurnal Keperawatan Indonesia 2, no. 1 (2017): 17.

${ }^{26}$ Ali Anwar, Pembaruan Pendidikan di Pesantren Lirboyo Kediri, II (Kediri: IAIT Press, 2011), 11.
}

Tribakti: Jurnal Pemikiran Keislaman

Volume 32, Nomor 1, Juli 2021 


\section{Hasil dan Pembahasan}

\section{Implementasi Program Intensive Course (IC)}

Program IC merupakan salah satu program wajib yang diikuti oleh seluruh santri Pondok Pesantren Syarif Hidayatullah sejak berdiri pada tahun 2015 sampai sekarang, tent unya program IC pada tahun ini (2021) cukup berbeda dari tahun sebelumnya. Tahun 2020 program IC terpaksa tidak dilaksanakan. Menurut Bapak Ali Anwar selaku pengasuh pondok Syarif Hidayatullah, tahun 2020 tidak dapat melaksanakan program IC rutin disebabkan adanya pandemi yang tidak memperbolehkan melakukan pertemuan dengan banyak orang.

IC pada tahun 2021 rencana awal dimulai pada tanggal 17 Januari 2021 sampai dengan 20 Februari 2021. Namun, dengan adanya PPKM (Pemberlakuan Pembatasan Kegiatan Masyarakat) program IC terpaksa diundur dan dimulai pada tanggal 1 Februari 2021 sampai dengan 20 Februari 2021. Santri yang mengikuti IC di tahun ini tidak seperti tahun-tahun sebelumnya yang berjumlah hampir 150 santri, tahun ini hanya 89 santri yang dapat mengikuti IC.

Sebelum IC dilaksanakan, setiap santri yang ingin mengikuti IC harus membawa surat keterangan sehat dari dokter dan surat izin dari orangtua bagi santri yang tinggal disekitar Kediri. Sedangkan untuk santri yang di luar Kediri harus melampirkan rapid test dan surat izin dari orang tua. Berikut ini jadwal IC tiap semester:

Seluruh kegiatan IC wajib diikuti oleh semua santri yang berada di pondok. Setiap mata pelajaran berlangsung selama 60 menit (1 jam). Apabila ada santri yang tidak mengikuti kegiatan tanpa ada alasan yang jelas, maka pihak pengurus akan memberikan sanksi setiap pekan. Dari seluruh mata pelajaran yang diterapkan pada saat IC, peneliti hanya membahas tentang penerapan mata pelajaran bahasa Arab dan bahasa Inggris dalam penelitian ini.

Jadwal pelajaran setiap semester beserta guru yang mengajar tidak ada perbedaan kecuali dalam hal aspek materi yang hendak dicapai. Setiap IC pembelajaran difokuskan pada peningkatan kebahasaan. Seperti pelajaran bahasa Inggris yang fokus pada materi speaking. Miss Gita memberlakukan English zone setiap pertemuan yang berarti tidak diperbolehkan menggunakan bahasa selain bahasa Inggris pada saat pembelajaran. Namun, apabila beliau sedang menjelaskan materi, beliau menggunakan bahasa Inggris dan bahasa Indonesia untuk membantu santri yang kurang paham. Miss Gita meminta santri untuk mencoba berbicara bahasa Inggris tanpa merasa takut salah penggunaan 
grammar. Tidak dapat dipungkiri bahwa grammar adalah suatu hal yang penting untuk dipelajari dan diterapkan ketika seseorang akan berbicara bahasa Inggris. Namun, grammar bukan yang paling penting. ${ }^{27}$ Menurut pendapat Miss Gita, untuk belajar bahasa khususnya skill berbicara lebih dibutuhkan kepercayaan diri dan fokus. Apabila santri tidak memiliki rasa percaya diri yang cukup untuk berbicara bahasa Inggris, maka kemungkinan besar vocabulary dan grammar yang telah dikuasai akan hilang.

Hal ini sejalan dengan pendapat Didi Sudrajat dalam penelitiannya yang menyatakan bahwa grammar bukan satu-satunya hal terpenting untuk dipelajari oleh seorang pelajar. Terlebih lagi dalam proses belajar, pelajar harus dapat menerima masukan dan saran serta tetap mau belajar. Dalam berkomunikasi yang terpenting adalah penyampaian maksud dan tujuan berbicara dengan orang lain. ${ }^{28}$ Maka dari itu, Miss. Gita memberikan materi mengenai penggunaan grammar seperti present tense dengan disertakan contoh penggunaannya dalam kehidupan sehari-hari agar santri dapat mempraktikkan bahasa tersebut secara langsung saat beraktifitas di luar jam pelajaran. Dari sini, peneliti berpendapat bahwa dalam mata pelajaran bahasa Inggris di program IC, santri diwajibkan berbicara bahasa Inggris sesuai dengan kemampuannya, tetapi santri tidak menutup diri untuk terus belajar untuk mengasah kemampuan berbicara bahasa Inggris sesuai dengan kaidah.

Begitu juga dengan ustadzah Frida yang mengajar bahasa Arab, beliau memfokuskan pada materi mahārah al-kalām. Setiap pertemuan ustadzah Frida meminta santri untuk percaya diri berbicara bahasa Arab meski tidak sedikit santri merasa kesulitan menerjemahkan Bahasa Indonesia ke bahasa Arab. Namun beliau bersedia membantu apabila santri meminta bantuan untuk menerjemahkan Bahasa Indonesia ke bahasa Arab. Di awal pertemuan, ustadzah Frida meminta santri untuk memilih pidato, MC, bercerita, dan menyanyi dalam bahasa Arab. Namun, untuk bagian MC dibatasi 12 santri.

Kemudian dipertemuan selanjutnya, ustadzah Frida meminta untuk santri mempraktikkan bidang yang telah ditentukan sesuai dengan pembagian pertemuan pertama. Tentunya dalam praktik ini harus totalitas seolah-olah mengikuti sebuah acara. Setelah itu, santri lain diminta untuk memberikan komentar mengenai penampilan

${ }^{27}$ Dewi Kustanti dan Yadi Prihmayadi, "Problematika Budaya Berbicara Bahasa Inggris," Jurnal al-Tsaqafa 14, no. 1 (2017): 54, https://doi.org/10.15575/al-tsaqafa.v14i1.1798.

${ }_{28}$ Didi Sudrajat, "Studi Tentang Pelaksanaan Pengajaran Bahasa Inggris di SD Kota Tenggarong," Cendikia 9, no. 1 (2015): 19.

Tribakti: Jurnal Pemikiran Keislaman

Volume 32, Nomor 1, Juli 2021 
temannya serta ada tambahan dan arahan yang lebih detail dari ustadzah Frida. Beliau tidak membedakan antar semester. Tugas yang diberikan setiap tingkat semester pasti sama.

Pembelajaran pada program IC cukup banyak. Namun, mata pelajaran yang diunggulkan pada program IC adalah bahasa Inggris dan bahasa Arab. Hal ini karena mata pelajaran bahasa Arab dan Inggris akan dilanjutkan di program reguler. Namun, untuk mata pelajaran yang lain, hanya difokuskan di IC dan pada saat reguler akan ada materi baru di setiap mata pelajaran. Dapat dikatakan bahwa pembelajaran bahasa Inggris dan bahasa Arab selalu berkesinambungan antar program IC dan reguler.

Melalui wawancara dengan pengurus pondok, pembelajaran bahasa Arab dan bahasa Inggris pada program IC fokus pada aspek bahasa bertujuan untuk meningkatkan kemampuan dan keberanian santri untuk berbicara selain bahasa Indonesia dan bahasa Jawa karena sebagian orang yang memiliki banyak teori tetapi sedikit orang yang mau atau berani untuk menerapkan teori tersebut. Aulia selaku ketua Pondok Pesantren Syarif Hidayatullah mengamati bahwa ilmu-ilmu kebahasaan yang didapatkan pada saat IC akan digunakan juga ketika pembelajaran reguler berlangsung. Setiap satu minggu dua kali akan diadakan hari bahasa, yang mana santri tidak diperbolehkan untuk berbicara bahasa Indonesia. Bahasa yang digunakan saat itu adalah bahasa Inggris atau bahasa Arab sesuai dengan jadwal yang telah ditetapkan. Hal ini dilakukan agar kemampuan berbicara bahasa asing meningkat.

Selaku pengasuh pondok, Bapak Ali Anwar tidak keberatan apabila diterapkan hari bahasa, beliau justru mendukung dan bersedia memberikan fasilitas yang dibutuhkan untuk menunjang program-program pembelajaran yang memang bermanfaat untuk masa depan santri. Beliau berharap bahwa seluruh santrinya dapat menguasai setidaknya satu bahasa asing dan tidak ragu untuk menerapkannya kepada orang lain termasuk saat berbicara dengan beliau. Pernyataan dari Bapak Ali sejalan dengan pendapat dari Ahmad Nurcholis menyatakan bahwa materi yang baik adalah materi yang dapat diaplikasikan dan bahasa harus diaplikasikan kedalam kegiatan sehari-hari. Oleh karena itu model pembelajaran yang tepat adalah setelah mendapatkan teori atau materi dari guru, harus dipraktikan langsung. ${ }^{29}$

\footnotetext{
${ }^{29}$ Ahmad Nurcholis, "Kontekstualisasi Manajemen Program Iintensive Coursebahasa Arab di IAIN Tulungagung," dalam Kreativitas dan Inovasi dalam Pembelajaran Bahasa Arab di Indonesia, 2017, 43. 
Sejalan dengan penerapan dari program IC yang telah terlaksana sebelumnya, maka santri menjadi lebih berani untuk menerapkan pelajaran bahasa yang telah dipelajari, dibuktikan dengan keberanian santri berbicara bahasa Inggris atau Arab pada saat hari bahasa. Meskipun tidak semua santri memiliki kosa kata bahasa asing banyak, akan tetapi mereka mampu menyampaikan maksud yang disampaikan dengan kemampuan yang dimiliki oleh masing-masing santri, juga dengan penggunaan grammar yang terbatas dimiliki santri karena alasan yang telah disampaikan sebelumnya. Sehingga tidak menjadi alasan untuk tidak berbicara saat hari bahasa.

Berbeda dengan program IC yang diterapkan di Pondok Pesantren Mahasiswa (PPM) Al-Jihad Surabaya, pondok tersebut menerapkan sistem pembelajaran yang sesuai dengan kebutuhan mahasiswa, sehingga selalu ada perkembangan mengenai sistem pembelajaran yang diterapkan, terutama pada jenis mata pelajaran yang diberikan di pondok. Namun, salah satu mata pelajaran yang wajib diberikan adalah bahasa Arab. Menurut pengurus di pondok tersebut, bahasa Arab merupakan bahasa yang penting untuk dipelajari karena al-Qur'ān menggunakan bahasa Arab. ${ }^{30}$ Sistem yang digunakan di pondok pesantren tersebut mengalami perkembangan dari sistem yang berbentuk bi'ah lughoh yang tidak hanya bertujuan agar santri mampu berbicara saja, tetapi santri diharapkan juga mampu memahami tata bahasa nahwu dan shorof. Sehingga dalam pelaksanaan program intensif tahun berikutnya mengalami perubahan fokus yaitu pada tata bahasa Arab nahwu dan shorof. Adapun setelah beberapa tahun kemudian sistem yang dikembangkan di PPM Al-Jihad Surabaya berubah kembali yang sampai saat ini masih diterapkan yaitu nadzariyah al wahdah merupakan sistem yang menggabungkan empat ketrampilan bahasa secara bersamaan yaitu kalām, istima, qirāah, dan kitābah beserta pemahaman terhadap qowaid. ${ }^{31}$

Program IC yang terlaksana di Pondok Pesantren Syarif Hidayatullah memiliki tujuan tersendiri yaitu pada ketrampilan berbicara, hal ini dikarenakan masih banyak santri yang belum memiliki keberanian untuk berbicara menggunakan bahasa asing, walaupun dalam kenyataannya para santri memiliki kemampuan memahami bahasa yang cukup baik. Dibuktikan saat salah satu santri berbicara bahasa asing, santri yang diajak berbicara dapat memahami dan mengerti maksud yang disampaikan, akan tetapi masih

${ }^{30}$ Wardatul Munawaroh, "Penerapan Sistem Nadzariyah Al-Wahdah pada Program Intensif Bahasa Arab di Pondok Pesantren Mahasiswa Al-Jihad Surabaya," Dar eL-Ilmi: Jurnal Studi Keagamaan, Pendidikan Humaniora 7, no. 2 (2020): 21.

${ }^{31}$ Munawaroh, 22.

Tribakti: Jurnal Pemikiran Keislaman Volume 32, Nomor 1, Juli 2021 
kebingungan dalam menjawab sehingga secara sadar dia akan menjawab dalam bahasa keseharian atau bahasa Indonesia.

\section{Tantangan Implementasi Program IC}

Program IC di Pondok Pesantren Syarif Hidayatullah sudah sering dilakukan, tetapi untuk pelaksanaan selama pandemi baru dilaksanakan pada tahun ini. Tentu saja segala rencana dalam pelaksanaannya membutuhkan perencanaan yang matang sehingga program IC dapat terlaksana dengan maksimal meski di tengah pandemi dan baru kali pertama diterapkan. Beberapa tantangan dalam implementasi program IC antara lain: kehadiran santri, bahan ajar terbatas, dan waktu yang singkat.

Kehadiran santri termasuk hal yang menjadi tolak ukar atas keberhasilan sebuah program pembelajaran yang ada di pondok. ${ }^{32}$ Sebuah program dapat dikatakan berhasil apabila banyak yang ikut berpartisipasi untuk kelancaran program tersebut. Apalagi mengingat pandemi maka kehadiran santri sangat berpengaruh. Meski tidak semua santri mengikuti program IC yang disebabkan karena terhalang izin orang tua untuk mengizinkan anak kembali ke pondok terutama santri yang ada di luar Kediri. Selain izin dari orang tua yang berupa surat pernyataan, santri juga harus menyertakan surat keterangan sehat dari dokter. Apabila kegiatan IC sebelum pandemi diikuti sekitar $90 \%$ santri, untuk tahun ini hanya 70\% santri yang dapat mengikuti program IC di pondok. Alasan yang paling mendasar adalah tidak mendapatkan izin orang tua untuk kembali ke pondok. Apabila menerapkan IC secara daring (dalam jaringan) dengan menggunakan aplikasi berbasis video dirasa kurang efektif, sebab para guru tidak dapat mengamati kegiatan santri secara detail, guru juga tidak dapat mengetahui gerakan tubuh dan bahasa santri saat mengikuti pembelajaran. ${ }^{33}$

Tidak terdapat bahan ajar yang dibutuhkan santri menjadi salah satu penyebab tantangan dalam pelaksanaan IC selama pandemi. Pondok pun tidak menyediakan buku atau modul yang dapat digunakan santri untuk belajar saat program IC. Sehingga santri tidak memiliki patokan materi yang sedang dibahas. Pada pelaksanaannya, santri diminta untuk menulis materi yang berkaitan dengan pembahasan yang sedang diajarkan. Meski tidak ada bahan ajar, ustadzah Frida dan Miss Gita melakukan

32 Astutik Yuli, "Strategi Pengelolaan Pesantren dalam Meningkatkan Kreativitas Santri melalui Pembentukan Orda (Studi Kasus di Pondok Pesantren Annuqayah Lubangsa Putri Guluk-Guluk, Sumenep)" (Madura, Institut Agama Islam Negeri (IAIN), 2020), 54.

${ }^{33}$ Sufirmansyah dkk., "Student's Preferences in Using Video-Based Learning Applications and Its Efficiency in Higher Education," Nazhruna: Jurnal Pendidikan Islam 4, no. 2 (2021): 275, https://doi.org/doi.org/10.31538/nzh.v4i2.1474. 
improvisasi dengan membuat bahan ajar untuk digunakan pribadi. Materi-materi yang diajarkan oleh beliau juga berasal dari pengembangan saat pembelajaran berlangsung. Sehingga, meskipun tidak ada bahan ajar, tujuan pembelajaran yang hendak dicapai dapat terwujud.

Waktu yang singkat pada pelaksaan program IC tahun ini juga menjadi salah satu tantangan dalam pengimplementasiannya. Apabila IC di tahun sebelumnya dilakukan kurang lebih selama dua bulan selama perkulihan libur semester, pada tahun ini hanya dilakukan tiga minggu terakhir saat perkulihan semester genap akan dimulai. Sehingga terkesan terburu-buru dan hanya melaksanakan program wajib semester yang perlu diadakan. Itulah yang membuat seluruh materi yang diajarkan oleh guru, serta tujuan pembelajaran yang hendak dicapai tidak secara maksimal dapat dipelajari oleh santri.

Meski tantangan-tantangan di atas terjadi, tidak membuat semangat dan kinerja pengurus, santri, dan terutama guru dalam menerapkan program IC selama pandemi. Terbukti pada program intensif berjalan dengan baik. Setidaknya, dengan adanya program IC di tahun ini dapat dijadikan sebagai sumber rujukan dan bahan evaluasi oleh pengurus apabila semester berikutnya diadakan IC namun tetap dalam kondisi pandemi, sehingga dalam pelaksanaan program IC yang akan datang, segala tantangan dan rintangan dapat diminimalisir.

\section{Kesimpulan}

Program IC yang diadakan di Pondok Pesantren Syarif Hidayatullah merupakan salah satu program yang bertujuan untuk meningkatkan kemampuan berbahasa santri. Setiap libur semester program ini berfokus pada mata pelajaran bahasa Arab dan bahasa Inggris, sehingga santri dapat menguasai salah satu bahasa asing tersebut. Pada tahun ini, program IC diadakan di tengah pandemi yang belum berakhir, namun setidaknya lebih baik daripada tahun-tahun sebelumnya.

Meski pengurus berusaha untuk membuat konsep program IC secara maksimal, dalam pelaksanaannya masih terdapat beberapa tantangan. Tantangan tersebut antara lain: kehadiran santri yang masih $70 \%$ dari total keseluruhan santri, tidak ada bahan ajar yang dapat digunakan sebagai pedoman untuk santri dalam proses pembelajaran, dan waktu yang relatif singkat membuat materi-materi yang diajarkan tidak dapat diterima dengan optimal. 
Mengingat bahwa bahasa Arab dan bahasa Inggris merupakan bahasa Asing yang juga menjadi mata pelajaran unggulan yang ada di pondok pesanren Syarif Hidayatullah. Dengan adanya program IC yang berfokus pada mata pelajaran tersebut diharapkan dapat meningkatkan kualitas Pondok Pesantren Syarif Hidayatullah. Sehingga program IC tetap dibutuhkan dan perlu dipertahankan meski terdapat beberapa tantangan. Namun, proses perencanaan, pelaksanaan, dan evaluasi program IC bahasa Arab dan bahasa Inggris tahun ini perlu dievaluasi dan ditingkatkan dari berbagai aspek.

\section{Daftar Pustaka}

Agave, Queen. "Teknik dokumentasi dan pelaporan dalam tataran klinik." Jurnal Keperawatan Indonesia 2, no. 1 (2017)

Agustini, Ketut, dan Jero Gede Ngarti. "Pengembangan Video Pembelajaran untuk Meningkatkan Motivasi Belajar Siswa Menggunakan Model R\&D.” Jurnal Ilmiah Pendidikan dan Pembelajaran 4, no. 1 (2020)

Akmalia, Frida, dan Syihabuddin. "Taqwîm Al Barnāmij Al Mukatstsaf Lita’lîm Al Lughah Al'arabiyyah Fî Al Madrasah Al Mutawassitah Al Islāmiyyah Al Hukūmiyyah Al Tsāniyah Kediri." Al-Mi'yar 3, no. 1 (2020).

Amalina, Nurul Hidayatul, dan Muh. Nashirudin. "Analisis Proses Pembelajaran Bahasa Arab Pada Tingkat Tsanawiyah di Pondok Pesantren Ta'mirul Islam.” Jurnal Tatsqif: Jurnal Pemikiran dan Penelitian Pendidika 15, no. 2 (2017) https://doi.org/10.20414/jtq.v15i2.7.

Anwar, Ali. Pembaruan Pendidikan di Pesantren Lirboyo Kediri. II. Kediri: IAIT Press, 2011.

_. "Syarif Hidayatullah Cyber Pesantren." Syarif Hidayatullah Cyber Pesantren (blog), 2018. https://syahidacyberpesantren.wordpress.com/.

Arifin, Zaenal, dan Moh. Turmudi. "Character of Education in Pesantren Perspective: Study of Various Methods of Educational Character at Pesantren in Indonesia." Tribakti: Jurnal Pemikiran Keislaman 30, no. 2 (Juli 2019) https://doi.org/10.33367/tribakti.v30i2.823.

Darmadji, Ahmad. "Pondok Pesantren dan Deradikalisasi Islam di Indonesia." Millah XI, no. 1 (2011) https://doi.org/10.20885/millah.vol11.iss1.art12.

Dipta, Dinar, dan Lies Amin Lestari. "Tenses Usage in Pre and Post Test Compositions of Intensive Course Program.” Jurnal Mahasiswa Unesa 4, no. 2 (2015)

Ferdinan, M. "Pondok Pesantren, Ciri Khas Perkembangannya." Jurnal Tarbawi 1, no. 1 (2019) https://doi.org/10.26618/jtw.v1i1.348.

Hidayati, Fitri, Zakiyah Arifa, Ainun Jariyah, dan Shofiatus Zahriyah. "Manajemen PengorganisasianProgram Bahasa Arab di Pondok Pesantren Salaf." Tarling: Journal of Language Education 3, no. 1 (2019) https://doi.org/tarling.v3i1.2031. 
Joesyiana, Kiki. "Penerapan Metode Pembelajaran Observasi Lapangan Pada Mata Kuliah Manajemen Operasional." Journal of Chemical Information and Modeling 53, no. 9 (2019).

Kariyanto, Hendi. "Peran Pondok Pesantren dalam Masyarakat Modern." Edukasia Multikultura 1, no. 1 (2019)

Khairurrijal. "Eksistensi Pondok Pesantren di Tengah Kemodernan Pesantren." Jurnal el-Hekam IV, no. 2 (2019) http://dx.doi.org/10.31958/jeh.v4i2.2013.

Khasanah, Dian Ratu Ayu Uswatun, Hascaryo Pramudibyanto, dan Barokah Widuroyekti. "Pendidikan dalam Masa Pandemi." Jurnal Sinestesia 10, no. 1 (2020).

Kustanti, Dewi, dan Yadi Prihmayadi. "Problematika Budaya Berbicara Bahasa Inggris." Jurnal al-Tsaqafa 14, no. 1 (2017) https://doi.org/10.15575/altsaqafa.v14i1.1798.

Marzuki, dan Ahmad Masrukin. "Motif Orang Tua Santri di Pondok Pesantren HM Lirboyo." Tribakti: Jurnal Pemikiran Keislaman 30, no. 1 (2019) https://doi.org/10.33367/tribakti.v30i1.667.

Mishra, Sita, dan Rajendra Nargundkar. "An Analysis of Intensive Mode Pedagogy in Management Education in India." International Journal of Educational Management 29, no. 4 (1 Januari 2015) https://doi.org/10.1108/IJEM-04-20140050 .

Munawaroh, Wardatul. "Penerapan Sistem Nadzariyah Al-Wahdah pada Program Intensif Bahasa Arab di Pondok Pesantren Mahasiswa Al-Jihad Surabaya." Dar eL-Ilmi: Jurnal Studi Keagamaan, Pendidikan Humaniora 7, no. 2 (2020).

Nurcholis, Ahmad. "Kontekstualisasi Manajemen Program Iintensive Coursebahasa Arab di IAIN Tulungagung." Dalam Kreativitas dan Inovasi dalam Pembelajaran Bahasa Arab di Indonesia, 2017.

Purwanto, Agus. "Studi Eksplorasi Dampak Work from Home (WFH) Terhadap Kinerja Guru Selama Pandemi Covid-19." Journal of Education, Psycology, and Counselling 2, no. 1 (2020).

Rachmawati, Imami Nur. "Pengumpulan Data Dalam Penelitian Kualitatif: Wawancara." Jurnal Keperawatan Indonesia 11, no. 1 (2007) https://doi.org/10.7454/jki.v11i1.184.

Ratna. "English Learning Strategies Used by Students at English 'Intensive Course' in Jombang." Universitas Brawijaya, 2017.

Rosalina, Faren, dan Loli Safitri. “An Analysis of Students' Difficulties In Learning Intensive Course at The First Semester Students of State Islamic Institute of Bukittinggi Academic Years 2019/2020.” Indonesian Journal of Learning Studies 1, no. 11 (2021) 
Sali, Abdul Haiy Abdul, dan Arlyne Canales Marasigan. "Madrasah Education Program Implementation in the Philippines: an Exploratory Case Study." International Journal of Comparative Education and Development 22, no. 3 (2020) https://doi.org/10.1108/IJCED-06-2019-0034.

Solichin, Mohammad Muchlis. "Intensive English Instructionin Pesantren (Study on Pondok Pesantren Puncak Darus Salam, Potoan Daja Palengaan Pamekasan).” OKARA: Jurnal Bahasa dan Sastra 12, no. 2 (2018) https://doi.org/10.19105/ojbs.v12i12.1991.

Sudrajat, Didi. "Studi Tentang Pelaksanaan Pengajaran Bahasa Inggris di SD Kota Tenggarong." Cendikia 9, no. 1 (2015)

Sufirmansyah, Laudria Nanda Prameswati, Dewi Trisna Wati, dan Sulistyowati. "Student's Preferences in Using Video-Based Learning Applications and Its Efficiency in Higher Education." Nazhruna: Jurnal Pendidikan Islam 4, no. 2 (2021). https://doi.org/doi.org/10.31538/nzh.v4i2.1474.

Tolib, Abdul. “Pendidikan di Pondok Pesantren Modern.” Jurnal Risaalah 1, no. 1 (2015)

Yuli, Astutik. "Strategi Pengelolaan Pesantren dalam Meningkatkan Kreativitas Santri melalui Pembentukan Orda (Studi Kasus di Pondok Pesantren Annuqayah Lubangsa Putri Guluk-Guluk, Sumenep).” Institut Agama Islam Negeri (IAIN), 2020.

Yunianti, Sofi, Teguh Adimarta, dan Vega Hesmatantya. "Peningkatan Kualitas Pembelajaran Berkarakter pada Perkuliahan Intensive Course.” Didaktis 15, no. 2 (2015) http://dx.doi.org/10.30651/didaktis.v15i2.81. 